\title{
Effects of methanolic extract form Fuzhuan brick-tea on hydrogen peroxide-induced oxidative stress in human intestinal epithelial adenocarcinoma Caco-2 cells
}

\author{
JIA-LE SONG $^{1}$ and YANG GAO ${ }^{2}$ \\ ${ }^{1}$ Department of Food Science and Nutrition, Pusan National University, Busan 609-735, Republic of Korea; \\ ${ }^{2}$ Department of Pharmacy, Northern Jiangsu People's Hospital Affiliated to Yangzhou University \\ (Clinical Medical College of Yangzhou University), Yangzhou, Jiangsu 225001, P.R. China
}

Received August 7, 2013; Accepted December 17, 2013

DOI: $10.3892 / \mathrm{mmr} .2014 .1884$

\begin{abstract}
The present study investigated the protective effect of methanolic extract from Fuzhuan brick-tea (FME) on hydrogen peroxide $\left(\mathrm{H}_{2} \mathrm{O}_{2}\right)$-induced oxidative stress in the human intestinal epithelial adenocarcinoma cell line Caco-2. Caco-2 cells were pretreated with different concentrations (50, 100 and $200 \mu \mathrm{g} / \mathrm{ml}$ ) of FME for $2 \mathrm{~h}$ and then exposed to $\mathrm{H}_{2} \mathrm{O}_{2}$ $(1 \mathrm{mM})$ for $6 \mathrm{~h}$. FME did not exhibit a significant cytotoxic effect and increased the cell viability following $\mathrm{H}_{2} \mathrm{O}_{2}$ treatment by decreasing lipid peroxidation in Caco-2 cells. To investigate the protective effect of FME on $\mathrm{H}_{2} \mathrm{O}_{2}$-induced oxidative stress in Caco-2 cells, the levels of intracellular glutathione (GSH) and the activity of the endogenous antioxidant enzymes catalase (CAT), superoxide dismutase (SOD), glutathione peroxidase (GSH-px) and glutathione S-transferase (GST), were determined. FME significantly increased the level of GSH and the activity of antioxidant enzymes. The results from the present study demonstrated that FME has a protective effect on $\mathrm{H}_{2} \mathrm{O}_{2}$-induced oxidative damage in Caco-2 cells through the inhibition of lipid peroxidation and the increase in the activity of antioxidant enzymes. In addition, FME reduced the $\mathrm{H}_{2} \mathrm{O}_{2}$-induced expression of interleukin- 8 at both the mRNA and protein levels in Caco-2 cells.
\end{abstract}

\section{Introduction}

Reactive oxygen species (ROS)-induced oxidative stress is caused by an imbalance between the antioxidant defense system and the generation of oxidants in the human body. It is associated with a number of human diseases, such as cardio-

Correspondence to: Ms. Yang Gao, Department of Pharmacy, Northern Jiangsu People's Hospital Affiliated to Yangzhou University (Clinical Medical College of Yangzhou University), 98 Nantong West Road, Yangzhou, Jiangsu 225001, P.R. China E-mail: gaoyang1983@outlook.com

Key words: Fuzhuan brick-tea, oxidative stress, antioxidant enzymes, interleukin-8, Caco-2 cells vascular disease (CVD), diabetes, inflammatory disease, aging and cancer (1-3). It is well known that the intestinal epithelium plays an important role in nutrient absorption, and serves as a physical barrier separating the host from the external environment, thereby contributing to the defense against pathogens and xenobiotics mediated by the gut immune system (4). Overproduction of ROS results in lipid peroxidation, protein oxidation and DNA damage, and induces cell damage in intestinal epithelial cells (1). ROS-induced intestinal epithelial cell damage has been associated with the pathogenesis of inflammatory bowel diseases (IBD), including Crohn's disease and ulcerative colitis (UC) (1). The endogenous antioxidant system, including glutathione (GSH) and antioxidant enzymes such as superoxide dismutase (SOD), catalase (CAT), glutathione peroxidase (GSH-px) and glutathione S-transferase (GST) acts as a scavenger of the accumulated ROS, and thereby protects organs and cells from ROS-induced oxidative damage (3). Dietary intake of beverages, such as polyphenol-enriched tea products, may increase the levels of protective antioxidants in the body and improve the activity of the human antioxidant defense system to prevent ROS-induced colitis (5-8).

In response to pathogens, oxidative stress and pro-inflammatory cytokines, such as the tumor necrosis factor (TNF)- $\alpha$, intestinal epithelial cells, increase the production of the chemokine interleukin-8 (IL-8), triggering an inflammatory reaction in the colonic mucosa that promotes IBD and colorectal carcinogenesis (9-11). Modulation of the IL-8 production in the intestinal epithelial cells is thus important to maintain intestinal health, and to attenuate the symptoms of IBD and colon cancer $(12,13)$.

Fuzhuan brick-tea is a traditional fermented tea prepared by incubating leaves of Camellia sinensis var sinensis with Eurotium spp. fungiat $26-28^{\circ} \mathrm{C}$ for $12-15$ days. Fuzhuan brick-tea is widely consumed by ethnic groups in the border regions of southern and western China (14). In China, Fuzhuan brick-tea is also used in folk medicine for its anti-dysenteric $(14,15)$, antibacterial $(15,16)$, anti-obesity and hypolipidemic activities (17).

The present study was designed to investigate the cytoprotective effects of methanolic extract from Fuzhuan brick-tea on $\mathrm{H}_{2} \mathrm{O}_{2}$-induced oxidative stress and to elucidate the underlying mechanisms in the human colon adenocarcinoma Caco- 2 cell 
line. These cells are considered as a good model to study the function of the small intestine and exhibit typical features of healthy human intestinal epithelial cells, such as brush border microvilli, tight junctions and dome formation (18).

\section{Materials and methods}

Chemical reagents. Dulbecco's modified Eagle's medium (DMEM), fetal bovine serum (FBS), nonessential amino acids, penicillin-streptomycin and $0.05 \%$ trypsin- $0.53 \mathrm{mM}$ EDTA were purchased from Gibco-BRL (Grand Island, NY, USA). 3-(4,5-Dimethylthiazol-2-yl)-2,5-diphenyl tetrazolium bromide (MTT), TRIzol reagent, oligo(dT) $)_{18}$ primers, murine maloney leukemia virus (MMLV) reverse transcriptase, RNase inhibitor, ethidium bromide (EtBr), and agarose were purchased from Invitrogen Life Technologies (Carlsbad, CA, USA). Additional chemicals that were used were of standard analytical grade.

Fuzhuan brick-tea extract preparation. Fuzhuan brick-tea was purchased from Yiyang Fucha Tea Industry Development Co., Ltd. (Hunan, China). A total of $50 \mathrm{~g}$ of lyophilized Fuzhuan brick-tea was used for three extractions in 20 -fold volume of methanol at room temperature and avoiding the light for $24 \mathrm{~h}$. The methanol extracts were combined, filtered on filter paper (Whatman International Ltd., Maidstone, UK) and vacuum-concentrated at $50^{\circ} \mathrm{C}$ in a rotary evaporator (Büchi RE 111; Büchi Labortechnik, Flawil, Switzerland). The Fuzhuan brick-tea methanolic extract (FME) was dissolved in dimethyl sulfoxide (DMSO) and stored at $-4^{\circ} \mathrm{C}$ until further analysis.

Cell culture. Human colon adenocarcinoma Caco-2 cells were obtained from the American Type Culture Collection (ATCC, Manassas, VA, USA). The cells were routinely maintained in DMEM medium supplemented with $20 \%$ (v/v) FBS, $1 \%$ penicillin-streptomycin, $1 \%$ glutamine and $1 \%$ non-essential amino acids in a humidified $5 \% \mathrm{CO}_{2}$ incubator (model 3110; Forma Scientific, Inc., Marietta, $\mathrm{OH}, \mathrm{USA}$ ) at $37^{\circ} \mathrm{C}$.

Cell viability assay. Cell viability was assessed using the MTT assay. The cells were seeded in 96-well plates (Nalge Nunc Int. Corp., Rochester, NY, USA) at a density of $1 \times 10^{4}$ cells/well. Following a 24-h incubation, the cells were primarily treated with different concentrations of FME $(25,100$ and $200 \mu \mathrm{g} / \mathrm{ml})$ for $2 \mathrm{~h}$, and exposed to $\mathrm{H}_{2} \mathrm{O}_{2}(1 \mathrm{mM})$ for $6 \mathrm{~h}$. Then, $100 \mu \mathrm{l}$ MTT reagent $(0.5 \mathrm{mg} / \mathrm{ml})$ was added to each well and the cells were incubated in a humidified incubator at $37^{\circ} \mathrm{C}$ to allow MTT to be metabolized. After 4 h, $100 \mu \mathrm{l}$ DMSO was added to each well to dissolve formazan deposits. The absorbance of the samples was measured at a $540 \mathrm{~nm}$ wavelength using a microplate reader (model 680; Bio-Rad, Hercules, CA, USA).

Quantification of lipid peroxidation. Lipid peroxidation was quantified using a thiobarbituric acid (TBA) reactive substance (TBARS) assay (19). First, the treated cells were washed with cooled phosphate-buffered saline (PBS) (pH 7.4, $0.1 \mathrm{M}$ ), scraped into trichloroacetic acid (TCA; 2.8\%, w/v) and sonicated at $40 \mathrm{~V} 3$ times at 10 -sec intervals on ice. Total cell protein concentrations were determined using a bicinchoninic acid (BCA) assay kit (Bio-Rad). The suspension was mixed with $1 \mathrm{ml}$ TBA $(0.67 \%, \mathrm{w} / \mathrm{v})$ and $1 \mathrm{ml} \mathrm{TCA}(25 \%, \mathrm{w} / \mathrm{v})$, heated $\left(30 \mathrm{~min}\right.$ at $\left.95^{\circ} \mathrm{C}\right)$ and centrifuged $(3,000 \mathrm{x} \mathrm{g} ; 10 \mathrm{~min}$ at $4^{\circ} \mathrm{C}$ ). TBA reacted with the products of oxidative degradation of lipids, producing red complexes, the absorbance of which was measured at $532 \mathrm{~nm}$ using a UV-2401PC spectrophotometer (Shimadzu, Kyoto, Japan).

Determination of intracellular glutathione (GSH) level. The intracellular GSH level was determined according to Ellman's method (20). The treated cells were washed with cooled PBS, collected and mixed with $10 \%$ sulfosalicylic acid solution to remove proteins, and centrifuged at $13,000 \mathrm{x}$ g for $10 \mathrm{~min}$ at $4^{\circ} \mathrm{C}$. The sample suspension $(50 \mu \mathrm{l})$ was mixed with $200 \mu \mathrm{l}$ Tris- $\mathrm{HCl}$ buffer ( $\mathrm{pH} 8.9,0.8 \mathrm{M}$ ) and $10 \mu 1$ 5,5'-dithiobis(2-nitrobenzoic acid) (DTNB; $4 \mathrm{mg} / \mathrm{ml}$ ) for $5 \mathrm{~min}$ at room temperature. The absorbance of the mixture was measured at a $412 \mathrm{~nm}$ wavelength using a UV-2401PC spectrophotometer (Shimadzu) for $5 \mathrm{~min}$.

Antioxidant enzyme activity. Caco-2 cells grown in a 6-well cell culture plate (Nalge Nunc Int. Corp.) were incubated with different concentrations $(25,100$ and $200 \mu \mathrm{g} / \mathrm{ml})$ of FME for $2 \mathrm{~h}$ and then exposed to $\mathrm{H}_{2} \mathrm{O}_{2}(1 \mathrm{mM})$ for $6 \mathrm{~h}$. The cells were washed with PBS, removed by scraping and centrifuged, and the resulting cell pellet was stored at $-80^{\circ} \mathrm{C}$. Cell pellets were thawed, resuspended in $300 \mu \mathrm{l}$ cold lysis buffer (PBS and $1 \mathrm{mM}$ EDTA), homogenized and centrifuged (12,000 x g; $10 \mathrm{~min}$ at $\left.4^{\circ} \mathrm{C}\right)$. The supernatants were used for activity measurements. CAT activity was assessed according to the method described by Nelson and Kiesow (21), which is based on spectrophotometric measurement, at $240 \mathrm{~nm}$, of the metabolized $\mathrm{H}_{2} \mathrm{O}_{2}$ substrate. SOD activity was assayed using a modified version of the method of auto-oxidation of pyrogallol (22). One unit of SOD activity was defined as the amount of enzyme that inhibited the auto-oxidation rate of pyrogallol by $50 \%$. GSH-px activity was assayed according to the method described by Hafeman et al (23). GST activity was determined according to the method of Habig et al (24), by measuring the absorption of the formed 2,4-dinitrochlorobenzene (CDNB)-GSH conjugate at $345 \mathrm{~nm}$. Protein contents were determined using a protein assay kit from Bio-Rad according to the manufacturer's instructions. All measured activities were expressed as units (U) of enzyme activity per mg protein.

IL-8 enzyme-linked immunosorbent assay (ELISA). Caco-2 cells grown in a 6-well cell culture plate were incubated with different concentrations of FME for $2 \mathrm{~h}$ and then exposed to $\mathrm{H}_{2} \mathrm{O}_{2}(1 \mathrm{mM})$ for $6 \mathrm{~h}$. At the end of the experiment, 100- $\mu \mathrm{l}$ aliquots were collected from culture medium of each well, and IL-8 production was measured using a commercially available ELISA kit (R\&D Systems, Minneapolis, MN, USA) following the manufacturer's protocol.

mRNA expression of IL-8 determined by RT-PCR. Expression of $I L-8$ in the cells was measured by RT-PCR. Total RNA was isolated with the TRIzol reagent and centrifuged at 12,000 $\mathrm{xg}$ for $15 \mathrm{~min}$ at $25^{\circ} \mathrm{C}$ following the addition of chloroform. Isopropanol was added to the supernatant at a 1:1 ratio and the RNA was pelleted by centrifugation $(12,000 \times \mathrm{g}$ for $15 \mathrm{~min}$ at $4^{\circ} \mathrm{C}$ ). After washing with $70 \%$ ethanol, the RNA was solubilized in diethyl pyrocarbonate (DEPC)-treated RNase-free double-distilled water and quantified by measuring the 


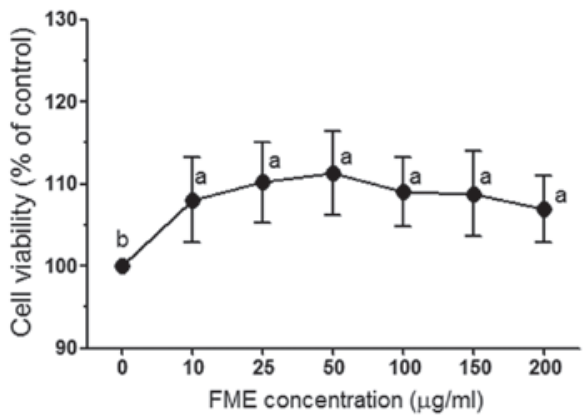

Figure 1. Effects of Fuzhuan brick-tea methanolic extract (FME) on cell viability in Caco-2 cells. Data are presented as mean \pm standard deviation (SD) of three independent experiments. Different letters (a and b) on the data points designate statistically significant differences $(\mathrm{P}<0.05)$ according to Duncan's multiple range test.

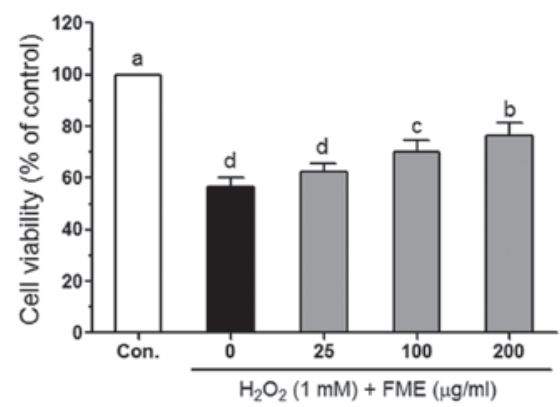

Figure 2. Effects of Fuzhuan brick-tea methanolic extract (FME) on cell viability in $1 \mathrm{mM}$ hydrogen peroxide $\left(\mathrm{H}_{2} \mathrm{O}_{2}\right)$-treated Caco-2 cells. Data are presented as mean \pm standard deviation $(\mathrm{SD})$ of three independent experiments. Different letters (a-d) on the bars designate statistically significant differences $(\mathrm{P}<0.05)$ according to Duncan's multiple range test. Con, control (healthy) cells.

absorbance in a UV-2401PC spectrophotometer (Shimadzu) at $260 \mathrm{~nm}$. Equal amounts of RNA $(1 \mu \mathrm{g})$ were reverse transcribed by incubating in an AccuPower PCR PreMix (Bioneer Corp., Daejeon, South Korea) containing $1 \mathrm{X}$ reverse transcriptase buffer, $1 \mathrm{mM}$ dNTPs, $500 \mathrm{ng}$ of oligo(dT) $)_{18}$ primers, 140 units of MMLV reverse transcriptase, and 40 units of RNase inhibitor, for $45 \mathrm{~min}$ at $42^{\circ} \mathrm{C}$. PCR was then performed in an automatic thermocycler (Bioneer Corp.) as follows: 28 cycles $\left(94^{\circ} \mathrm{C}\right.$ for $60 \mathrm{sec}, 57^{\circ} \mathrm{C}$ for $30 \mathrm{sec}$, and $72^{\circ} \mathrm{C}$ for $45 \mathrm{sec}$ ) and one cycle at $72^{\circ} \mathrm{C}$ for 5 -min, as previously described (25). PCR products were separated in $2 \%$ agarose gels and visualized by EtBr staining. $\beta$-actin was used for normalization.

Statistical analysis. Data are presented as the mean \pm standard deviation (SD). Differences between mean values of individual groups were assessed by one-way ANOVA with Duncan's multiple range tests. Differences were considered significant when $\mathrm{P}<0.05$. The SAS v9.1 statistical software package (SAS Institute Inc., Cary, NC, USA) was used for the analysis.

\section{Results}

Effects of FME on $\mathrm{H}_{2} \mathrm{O}_{2}$-induced cell damage in Caco-2 cells. To investigate FME-induced cytotoxicity, Caco-2 cells were incubated with different concentrations $(10,25,50,100$ and

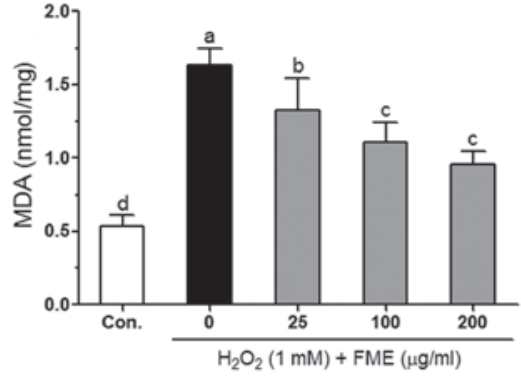

Figure 3. Effects of Fuzhuan brick-tea methanolic extract (FME) on the intracellular malonaldialdehyde (MDA) level in $1 \mathrm{mM}$ hydrogen peroxide $\left(\mathrm{H}_{2} \mathrm{O}_{2}\right)$-treated Caco-2 cells. Data are presented as mean \pm standard deviation (SD) of three independent experiments. Different letters on the bars $(\mathrm{a}-\mathrm{d})$ designate statistically significant differences $(\mathrm{P}<0.05)$ according to Duncan's multiple range test. Con, control (healthy) cells.

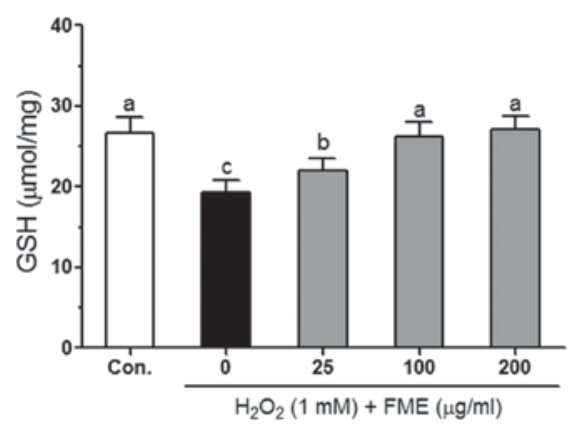

Figure 4. Effects of Fuzhuan brick-tea methanolic extract (FME) on the intracellular glutathione $(\mathrm{GSH})$ level in $1 \mathrm{mM}$ hydrogen peroxide $\left(\mathrm{H}_{2} \mathrm{O}_{2}\right)$-treated Caco- 2 cells. Data are presented as mean \pm standard deviation (SD) of three independent experiments. Different letters (a-c) on the bars designate statistically significant differences $(\mathrm{P}<0.05)$ according to Duncan's multiple range test. Con, control (healthy) cells.

$200 \mu \mathrm{g} / \mathrm{ml}$ ) of FME and the cell viability was determined by the MTT assay. After $24 \mathrm{~h}$ incubation, FME did not exert any significant cytotoxic effect in Caco-2 cells (Fig. 1). Therefore, the concentrations of 25,100 and $200 \mu \mathrm{g} / \mathrm{ml}$ were selected for subsequent experiments. $\mathrm{H}_{2} \mathrm{O}_{2}(1 \mathrm{mM})$ significantly reduced viability of Caco-2 cells (Fig. 2). However, following treatment with FME, cell viability increased in a dose-dependent manner.

Effects of FME on $\mathrm{H}_{2} \mathrm{O}_{2}$-induced lipid peroxidation in Caco-2 cells. ROS-induced oxidative damage is related to lipid peroxidation in the cell membrane, and is thus accompanied by an increase in the production of malondialdehyde (MDA), a biomarker of cell membrane lipid peroxidation (26). The MDA level markedly increased (up to 3-fold) in $1 \mathrm{mM} \mathrm{H}_{2} \mathrm{O}_{2}$-treated cells, reaching $1.64 \mathrm{nmol} / \mathrm{mg}$ compared to $0.54 \mathrm{nmol} / \mathrm{mg}$ detected in control cells (Fig. 3). FME dose-dependently reduced the $\mathrm{H}_{2} \mathrm{O}_{2}$-induced MDA level in Caco- 2 cells. At the concentration of $200 \mu \mathrm{g} / \mathrm{ml}$, FME significantly reduced the MDA level $(0.96 \mathrm{nmol} / \mathrm{mg})$ by $58 \%$ compared to control cells (treated only with $1 \mathrm{mM} \mathrm{H}_{2} \mathrm{O}_{2}$ ).

Effect of FME on the GSH level in $\mathrm{H}_{2} \mathrm{O}_{2}$-treated Caco-2 cells. The level of GSH, a major and ubiquitous non-enzymatic antioxidant compound, is important for the activity of the antioxidant defense system that protects from oxidative stress-induced cell 

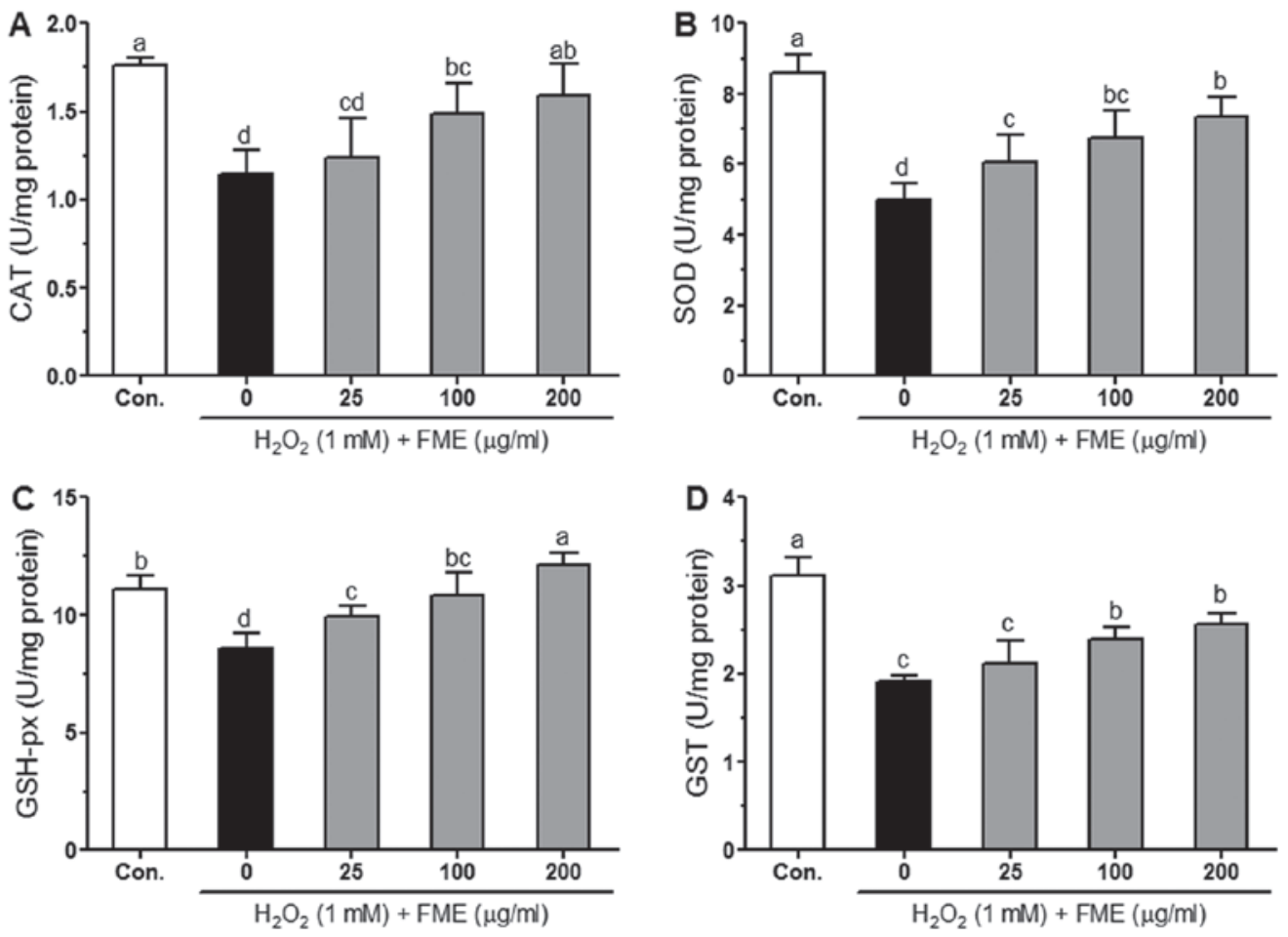

Figure 5. Effects of Fuzhuan brick-tea methanolic extract (FME) on the (A) activity of catalase (CAT), (B) superoxide dismutase (SOD), (C) glutathione peroxidase (GSH-px) and (D) glutathione S-transferase (GST) in $1 \mathrm{mM}$ hydrogen peroxide $\left(\mathrm{H}_{2} \mathrm{O}_{2}\right)$-treated Caco-2 cells. Data are presented as mean \pm standard deviation (SD) of three independent experiments. Different letters (a-d) on the bars designate statistically significant differences $(\mathrm{P}<0.05)$ according to Duncan's multiple range test. Con, control (healthy) cells.

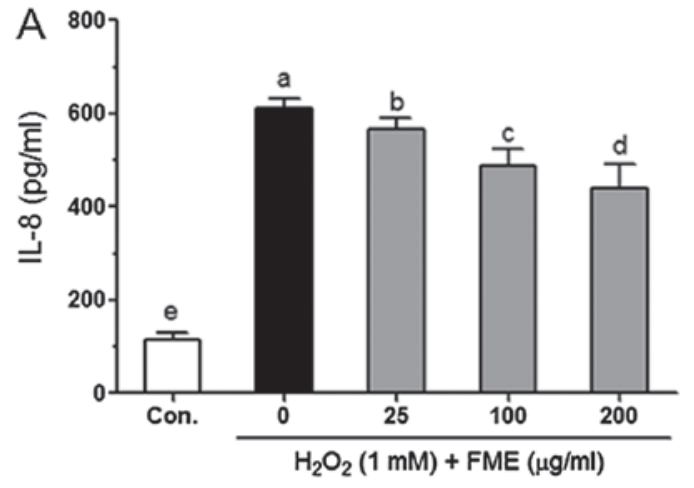

B

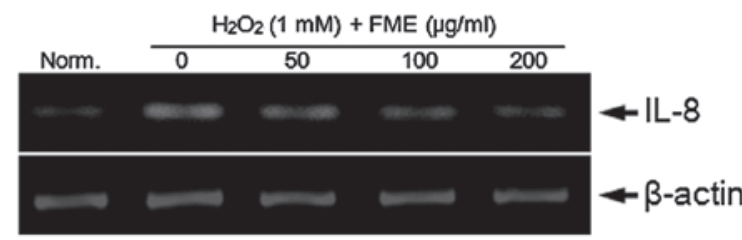

Figure 6. Effects of Fuzhuan brick-tea methanolic extract (FME) on (A) protein and (B) mRNA levels of IL-8 in $1 \mathrm{mM}$ hydrogen peroxide $\left(\mathrm{H}_{2} \mathrm{O}_{2}\right)$-treated Caco- 2 cells. Data are presented as mean \pm standard deviation (SD) of three independent experiments for (A) and as a representative blot with $\beta$-actin as the control for (B). Different letters (a-d) on the bars (A) designate statistically significant differences $(\mathrm{P}<0.05)$ according to Duncan's multiple range test. Con, control (healthy) cells.

damage (27). Treatment with $1 \mathrm{mM} \mathrm{H}_{2} \mathrm{O}_{2}$ reduced the GSH level $(19.35 \mathrm{nmol} / \mathrm{mg})$ in the Caco-2 cells compared to control cells (26.64 nmol/mg) (Fig. 4). Pretreatment with different concentrations of FME significantly increased the intracellular
GSH level compared to control cells (treated only with $1 \mathrm{mM}$ $\mathrm{H}_{2} \mathrm{O}_{2}$ ).

Effect of FME on CAT, SOD, GSH-px and GST activity in $\mathrm{H}_{2} \mathrm{O}_{2}$-treated Caco-2 cells. It is well known that the activity of endogenous antioxidant enzymes such as CAT, SOD, GSH-px and GST protects cells from ROS-induced oxidative damage (28). The effects of FME on antioxidant enzyme activities in $\mathrm{H}_{2} \mathrm{O}_{2}$-treated Caco-2 cells are shown in Fig. 5. $\mathrm{H}_{2} \mathrm{O}_{2}(1 \mathrm{mM})$ significantly $(\mathrm{P}<0.05)$ decreased the CAT, SOD, GSH-px and GST activities compared to control cells. Pretreatment with FME increased the activity of these enzymes, most often in a significant manner as compared to $\mathrm{H}_{2} \mathrm{O}_{2}$-treated cells. The increase in the activity of the enzymes was in general dose-dependent, with the most significant results observed for the GSH-px enzyme.

Effect of FME on the transcription and translation of IL-8 in $\mathrm{H}_{2} \mathrm{O}_{2}$-treated $\mathrm{Caco}-2$ cells. Oxidative stress was reported to induce IL-8 production in Caco-2 cells (25). The IL-8 level was significantly increased in response to treatment with $1 \mathrm{mM} \mathrm{H}_{2} \mathrm{O}_{2}$ for $6 \mathrm{~h}$ compared to control cells (Fig. 6A). Pretreatment with FME significantly and dose-dependently reduced the $\mathrm{H}_{2} \mathrm{O}_{2}$-induced IL- 8 production in Caco- 2 cells. FME also reduced the $\mathrm{H}_{2} \mathrm{O}_{2}$-induced mRNA level of $I L-8$ in Caco-2 cells (Fig. 6B).

\section{Discussion}

Fuzhuan brick-tea is a traditional Chinese fermented tea, rich in rutin, quercetin, gallic acid, catechin, epicatechin (EC), 
epigallocatechin (EGC), epicatechin gallate (ECG), epigallocatechin gallate (EGCG) and gallocatechin gallate (GCG) (17). The cytoprotective activity of Fuzhuan brick-tea has not been studied. Recent studies indicated that elevated ROS levels induce an inflammatory reaction, cause death of intestinal epithelial cells, and promote IBD and colon cancer $(1,29)$. The present study was conducted in order to investigate the potential cytoprotective and anti-inflammatory effect of FME in $\mathrm{H}_{2} \mathrm{O}_{2}$-stimulated human intestinal epithelial adenocarcinoma Caco-2 cells.

The intestinal epithelial cells are the major constituent of the mucosal barrier, and as such, play an important role in pathogenic microbe-induced infections, and in maintaining immune homeostasis in the colon (30). The human colon contains $>1,000$ microbial species with $>10^{14}$ colony-forming units (CFU) per gram of feces $(31,32)$. The intestinal microbial communities are closely associated with the pathogenesis of IBD (33). For example, Enterococcus faecalis produces extracellular superoxide $\left(\mathrm{O}_{2}{ }^{\circ}\right)$ and $\mathrm{H}_{2} \mathrm{O}_{2}$, and was shown to cause intestinal epithelial cell death (34). The reactive oxygen species $\mathrm{H}_{2} \mathrm{O}_{2}$ can easily cross cell membranes and react with $\mathrm{Fe}^{2+}$ to generate highly reactive $\cdot \mathrm{OH}$ radicals through the so-called Fenton's reaction. $\mathrm{OH}$ radicals attack a number of cellular compounds, such as DNA, proteins and membrane lipids, and thus cause cell damage (35). $\mathrm{H}_{2} \mathrm{O}_{2}$ was reported to significantly decrease the viability of Caco-2 cells and to increase the generation of MDA, a final product of lipid peroxidation (36). MDA is a cytotoxic product (37) that has been associated with the pathogenesis of colon diseases, in particular IBD and colon cancer (38). In the present study, we show that $1 \mathrm{mM}$ $\mathrm{H}_{2} \mathrm{O}_{2}$ significantly increased the MDA level in Caco-2 cells. However, pretreatment with different concentrations $(25,100$ and $200 \mu \mathrm{g} / \mathrm{ml}$ ) of FME effectively reduced the $\mathrm{H}_{2} \mathrm{O}_{2}$-induced increase in the MDA level. In addition, numerous studies have demonstrated that treatment with several plant-derived antioxidants such as rutin, quercetin, EGCG and polyphenols can ameliorate the $\mathrm{H}_{2} \mathrm{O}_{2}$-induced production of MDA in Caco-2 cells (39-43).

GSH is a major non-enzymatic antioxidant, and protects Caco- 2 cells from $\mathrm{H}_{2} \mathrm{O}_{2}$-induced cell damage $(36,44)$. We show that $\mathrm{H}_{2} \mathrm{O}_{2}$ significantly decreased the GSH level in Caco- 2 cells. However, we found that pretreatment with FME dose-dependently inhibited the $\mathrm{H}_{2} \mathrm{O}_{2}$-induced decrease in the GSH level. Aherne et al (45) reported that pretreatment with different plant extracts such as sage (Salvia officinalis L.), echinacea (Echinacea purpurea L.) and oregano (Origaum vulgare L.) increased the intracellular GSH levels, thereby protecting Caco- 2 cells from $\mathrm{H}_{2} \mathrm{O}_{2}$-induced cell damage. Our results indicate that an increased GSH level achieved by pretreatment with FME can also protect Caco- 2 cells from $\mathrm{H}_{2} \mathrm{O}_{2}$-induced oxidative stress.

In mammalian cells, accumulating free radicals and ROS are scavenged by the endogenous antioxidant system, comprising GSH and the antioxidant enzymes CAT, SOD, GSH-px and GST (3). SOD catalyzes the conversion of $\mathrm{O}_{2}{ }^{\cdot}$ to $\mathrm{H}_{2} \mathrm{O}_{2}$ and $\mathrm{H}_{2} \mathrm{O}_{2}$ is further reduced to $\mathrm{H}_{2} \mathrm{O}$ by CAT and $\mathrm{GSH}-\mathrm{px}$. A few studies have reported that lack of the endogenous antioxidant enzymes correlates to development of colitis and colon cancer, while increased activity of antioxidant enzymes in the colon effectively reduces oxidative stress-induced colonic tissue damage (5-8). In the present study, we found that CAT and SOD activities are significantly decreased following exposure to $\mathrm{H}_{2} \mathrm{O}_{2}(1 \mathrm{mM})$, and this finding is in agreement with results from the study of Katayama et al (44). We also found that pretreatment with FME significantly increased the CAT and SOD activities in $\mathrm{H}_{2} \mathrm{O}_{2}$-treated Caco-2 cells. Treatment with different dietary flavonoids (such as kaempferol and quercetin) increased the CAT activity in Caco-2 cells (46). Wijeratne and Cuppett (47) also reported that carnosol and carnosic acid significantly increased the SOD activity and protected Caco-2 cells from lipid hydroperoxide-mediated oxidative stress. However, treatment with rutin and quercetin did not significantly affect the activity of CAT and SOD in Caco-2 cells treated with $\mathrm{H}_{2} \mathrm{O}_{2}$ (40). GSH-px, the most important enzymatic scavenger of $\mathrm{H}_{2} \mathrm{O}_{2}$, is involved in detoxification from lipid hydroperoxides (48). Increasing the activity of GSH-px prevented the transport of lipid hydroperoxides in Caco-2 cells (49). Pretreatment with FME elevated the intracellular GSH-px activity in cells treated with $1 \mathrm{mM}$ $\mathrm{H}_{2} \mathrm{O}_{2}$ for $6 \mathrm{~h}$ compared to control cells (treated with $\mathrm{H}_{2} \mathrm{O}_{2}$ alone). Carrasco-Pozo et al (50) reported that treatment with quercetin, epicatechin and rutin protects Caco-2 cells from indometacin-induced oxidative damage, by increasing the ratio of GSH/oxidized glutathione (GSSG). In addition, quercetin, catechin and epicatechin were also shown to protect human astrocytoma U373 MG cells from $\mathrm{H}_{2} \mathrm{O}_{2}$-induced cell damage by increasing the GSH-px activity (51). Treatment with other antioxidants, such as carnosol and carnosic acid, also increased the GSH-px activity, thereby protecting Caco-2 cells from lipid hydroperoxide-mediated oxidative stress (47). GST is a detoxification enzyme expressed in most mammalian cells, and catalyzes the conjugation of electrophilic compounds to glutathione (52), providing protection from $\mathrm{H}_{2} \mathrm{O}_{2}$-induced cell death (53). Pretreatment with FME dose-dependently increased the GST activity in $\mathrm{H}_{2} \mathrm{O}_{2}$-treated Caco- 2 cells. Increasing the activity of GST was reported to cause a reduction in $\mathrm{H}_{2} \mathrm{O}_{2}$-induced damage in Caco-2 cells $(44,54)$. These results suggest that Fuzhuan brick-tea that is enriched in phytochemicals can act as a chemoprotective agent, protecting Caco- 2 cells from $\mathrm{H}_{2} \mathrm{O}_{2}$-induced oxidative stress by enhancing the activity of the endogenous antioxidant system.

In response to external stimuli, such as bacteria, toxins, chemicals and oxidative stress, intestinal epithelial cells overexpress and secrete the chemokine IL-8 (9-11). In IBD and colon cancer pathogenesis, IL-8 plays an important role in inducing the infiltration of neutrophiles and $\mathrm{T}$ cells into the intestinal mucosa $(55,56)$. A number of studies demonstrated that treatment with 5-caffeoylquinic acid, caffeic acid and isoflavones effectively reduces the $\mathrm{H}_{2} \mathrm{O}_{2}$ and TNF- $\alpha$-induced IL-8 overproduction, as well as the overexpression of the $I L-8$ gene $(57,58)$. In this study, we found that pretreatment with FME effectively attenuated the $\mathrm{H}_{2} \mathrm{O}_{2}$-induced IL- 8 overproduction, and also reduced the mRNA expression of $I L-8$ in Caco- 2 cells exposed to $\mathrm{H}_{2} \mathrm{O}_{2}$. In addition, Netsch et al (59) reported that treatment with $250 \mu \mathrm{g} / \mathrm{ml}$ of green tea extract significantly reduces the production $(\mathrm{P}<0.05)$ and mRNA expression $(\mathrm{P}<0.01)$ of IL-8 in IL-1 $\beta$-stimulated Caco- 2 cells.

In conclusion, we demonstrated that FME can protect Caco-2 cells from $\mathrm{H}_{2} \mathrm{O}_{2}$-induced oxidative stress. This is accomplished through an increase in the intracellular GSH 
level, in the activity of endogenous antioxidant enzymes (CAT, SOD, GSH-px and GST), as well as through a reduction in $\mathrm{H}_{2} \mathrm{O}_{2}$-induced production of MDA. Our results also show that FME significantly reduced the protein and mRNA level of IL-8 in the $\mathrm{H}_{2} \mathrm{O}_{2}$-treated human colon adenocarcinoma cell line Caco-2. The results from the present study suggest that Fuzhuan brick-tea may serve as a preventive agent in the treatment of intestinal inflammations.

\section{References}

1. Rezaie A, Parker RD and Abdollahi M: Oxidative stress and pathogenesis of inflammatory bowel disease: an epiphenomenon or the cause? Dig Dis Sci 52: 2015-2021, 2007.

2. Brieger K, Schiavone S, Miller FJ Jr and Krause KH: Reactive oxygen species: from health to disease. Swiss Med Wkly 142 w13659, 2012.

3. Halliwell B: Reactive species and antioxidants. Redox biology is a fundamental theme of aerobic life. Plant Physiol 141: 312-322, 2006.

4. Bourlioux P, Koletzko B, Guarner F and Braesco V: The intestine and its microflora are partners for the protection of the host: report on the Danone Symposium 'The Intelligent Intestine', held in Paris, June 14, 2002. Am J Clin Nutr 78: 675-683, 2003.

5. Oz HS, Chen TS, McClain CJ and de Villiers WJ: Antioxidants as novel therapy in a murine model of colitis. J Nutr Biochem 16 297-304, 2005

6. Mazzon E, Muià C, Paola RD, et al: Green tea polyphenol extract attenuates colon injury induced by experimental colitis. Free Radic Res 39: 1017-1025, 2005.

7. Song YA, Park YL, Kim KY, et al: Black tea extract prevents lipopolysaccharide-induced $\mathrm{NF}-\kappa \mathrm{B}$ signaling and attenuates dextran sulfate sodium-induced experimental colitis. BMC Complement Altern Med 11: 91, 2011.

8. Brückner M, Westphal S, Domschke W, Kucharzik T and Lügering A: Green tea polyphenol epigallocatechin-3-gallate shows therapeutic antioxidative effects in a murine model of colitis. J Crohns Colitis 6: 226-235, 2012

9. Eckmann L, Kagnoff M and Fierer J: Epithelial cells secrete the chemokine interleukin-8 in response to bacterial entry. Infect Immun 61: 4569-4574, 1993.

10. Verhasselt V, Goldman M and Willems F: Oxidative stress up-regulates IL- 8 and TNF-alpha synthesis by human dendritic cells. Eur J Immunol 28: 3886-3890, 1998.

11. Yamamoto K, Kushima R, Kisaki O, Fujiyama Y and Okabe $\mathrm{H}$ Combined effect of hydrogen peroxide induced oxidative stress and IL-1alpha on IL-8 production in CaCo-2 cells (a human colon carcinoma cell line) and normal intestinal epithelial cells Inflammation 27: 123-128, 2003.

12. Nielsen O, Rüdiger N, Gaustadnes $M$ and Horn T: Intestinal interleukin-8 concentration and gene expression in inflammatory bowel disease. Scand J Gastroenterol 32: 1028-1034, 1997.

13. Strober W, Fuss I and Mannon P: The fundamental basis of inflammatory bowel disease. J Clin Invest 117: 514-521, 2007.

14. Ling TJ, Wan XC, Ling WW, et al: New triterpenoids and other constituents from a special microbial-fermented tea-Fuzhuan brick tea. J Agric Food Chem 58: 4945-4950, 2010.

15. Mo H, Zhu Y and Chen Z: Microbial fermented tea: a potential source of natural food preservatives. Trends Food Sci Tech 19: $124-130,2008$

16. Luo Z-M, Ling TJ, Li LX, et al: A new norisoprenoid and other compounds from Fuzhuan brick tea. Molecules 17: 3539-3546, 2012 .

17. Li Q, Liu Z, Huang J, et al: Anti-obesity and hypolipidemic effects of Fuzhuan brick tea water extract in high-fat diet-induced obese rats. J Sci Food Agric 93: 1310-1316, 2013.

18. Pinto M, Robine-Leon S, Appay MD, et al: Enterocyte-like differentiation and polarization of the human colon carcinoma cell line Caco-2 in culture. Biol Cell 47: 323-330, 1983.

19. Fraga CG, Leibovitz BE and Tappel AL: Lipid peroxidation measured as thiobarbituric acid-reactive substances in tissue slices: characterization and comparison with homogenates and microsomes. Free Radic Biol Med 4: 155-161, 1988.

20. Ellman GL: Tissue sulfhydryl groups. Arch Biochem Biophys 82: 70-77, 1959.
21. Nelson D and Kiesow L: Enthalpy of decomposition of hydrogen peroxide by catalase at 25 degrees $\mathrm{C}$ (with molar extinction coefficients of $\mathrm{H}_{2} \mathrm{O}_{2}$ solutions in the UV). Anal Biochem 49: 474-478, 1972.

22. Marklund S and Marklund G: Involvement of the superoxide anion radical in the autoxidation of pyrogallol and a convenient assay for superoxide dismutase. Eur J Biochem 47: 469-474, 1974.

23. Hafeman D, Sunde R and Hoekstra W: Effect of dietary selenium on erythrocyte and liver glutathione peroxidase in the rat. J Nutr 104: 580-587, 1974.

24. Habig WH, Pabst MJ and Jakoby WB: Glutathione S-transferases. The first enzymatic step in mercapturic acid formation. J Biol Chem 249: 7130-7139, 1974.

25. Bai B, Yamamoto K, Sato H, Sugiura $H$ and Tanaka T: Combined effect of 25-hydroxycholesterol and IL-1 $\beta$ on IL-8 production in human colon carcinoma cell line (Caco-2). Inflammation 29: 141-146, 2005.

26. Gutteridge J: Lipid peroxidation and antioxidants as biomarkers of tissue damage. Clin Chem 41: 1819-1828, 1995.

27. Masella R, Di Benedetto R, Varì R, Filesi C and Giovannini C: Novel mechanisms of natural antioxidant compounds in biological systems: involvement of glutathione and glutathione-related enzymes. J Nutr Biochem 16: 577-586, 2005.

28. Valko M, Leibfritz D, Moncol J, Cronin MT, Mazur M and Telser J: Free radicals and antioxidants in normal physiological functions and human disease. Int J Biochem Cell Biol 39: 44-84, 2007.

29. Zhu H and Li YR: Oxidative stress and redox signaling mechanisms of inflammatory bowel disease: updated experimental and clinical evidence. Exp Biol Med (Maywood) 237: 474-480, 2012.

30. Goto Y and Ivanov II: Intestinal epithelial cells as mediators of the commensal-host immune crosstalk. Immunol Cell Biol 91: 204-214, 2013

31. Eckburg PB, Bik EM, Bernstein CN, et al: Diversity of the human intestinal microbial flora. Science 308: 1635-1638, 2005.

32. Qin J, Li R, Raes J, et al: A human gut microbial gene catalogue established by metagenomic sequencing. Nature 464: 59-65, 2010.

33. Macfarlane S, Steed $\mathrm{H}$ and Macfarlane GT: Intestinal bacteria and inflammatory bowel disease. Crit Rev Clin Lab Sci 46: 25-54, 2009.

34. Huycke MM, Abrams V and Moore DR: Enterococcus faecalis produces extracellular superoxide and hydrogen peroxide that damages colonic epithelial cell DNA. Carcinogenesis 23: 529-536, 2002

35. Halliwell B: Antioxidants in human health and disease. Annu Rev Nutr 16: 33-50, 1996

36. Wijeratne SS, Cuppett SL and Schlegel V: Hydrogen peroxide induced oxidative stress damage and antioxidant enzyme response in Caco-2 human colon cells. J Agric Food Chem 53: 8768-8774, 2005

37. Ji C, Rouzer CA, Marnett LJ and Pietenpol JA: Induction of cell cycle arrest by the endogenous product of lipid peroxidation, malondialdehyde. Carcinogenesis 19: 1275-1283, 1998.

38. Nair U, Bartsch H and Nair J: Lipid peroxidation-induced DNA damage in cancer-prone inflammatory diseases: a review of published adduct types and levels in humans. Free Radic Biol Med 43: 1109-1120, 2007

39. Manna C, Galletti P, Cucciolla V, Moltedo O, Leone A and Zappia V: The protective effect of the olive oil polyphenol (3,4-dihydroxyphenyl)-ethanol counteracts reactive oxygen metabolite-induced cytotoxicity in Caco-2 cells. J Nutr 127: 286-292, 1997.

40. Aherne S and O'Brien N: Protection by the flavonoids myricetin, quercetin, and rutin against hydrogen peroxide-induced DNA damage in Caco-2 and HepG2 cells. Nutr Cancer 34: 160-166, 1999.

41. Aherne $\mathrm{S}$ and O'Brien N: Lack of Effect of the flavonoids, myricetin, quercetin, and rutin, on repair of $\mathrm{H}_{2} \mathrm{O}_{2}$-induced DNA single-strand breaks in Caco-2, HepG2, and V79 Cells. Nutr Cancer 38: 106-115, 2000.

42. Peng IW and Kuo SM: Flavonoid structure affects the inhibition of lipid peroxidation in Caco-2 intestinal cells at physiological concentrations. J Nutr 133: 2184-2187, 2003.

43. Intra J and Kuo SM: Physiological levels of tea catechins increase cellular lipid antioxidant activity of vitamin $\mathrm{C}$ and vitamin $\mathrm{E}$ in human intestinal caco-2 cells. Chem Biol Interact 169: 91-99, 2007. 
44. Katayama S, Ishikawa S, Fan MZ and Mine Y: Oligophosphopeptides derived from egg yolk phosvitin up-regulate gamma-glutamylcysteine synthetase and antioxidant enzymes against oxidative stress in Caco-2 cells. J Agric Food Chem 55 2829-2835, 2007.

45. Aherne SA, Kerry JP and O'Brien NM: Effects of plant extracts on antioxidant status and oxidant-induced stress in Caco-2 cells. Br J Nutr 97: 321-328, 2007.

46. Kameoka S, Leavitt P, Chang $\mathrm{C}$ and Kuo SM: Expression of antioxidant proteins in human intestinal Caco-2 cells treated with dietary flavonoids. Cancer Lett 146: 161-167, 1999.

47. Wijeratne SS and Cuppett SL: Potential of rosemary (Rosemarinus officinalis L.) diterpenes in preventing lipid hydroperoxide-mediated oxidative stress in Caco-2 cells. J Agric Food Chem 55: 1193-1199, 2007.

48. Aw TY: Determinants of intestinal detoxication of lipid hydroperoxides. Free Radic Res 28: 637-646, 1998.

49. Wingler K, Müller C, Schmehl K, Florian S and Brigelius-Flohé R: Gastrointestinal glutathione peroxidase prevents transport of lipid hydroperoxides in $\mathrm{CaCo}-2$ cells. Gastroenterology 119 420-430, 2000

50. Carrasco-Pozo C, Gotteland M and Speisky H: Protection by apple peel polyphenols against indometacin-induced oxidative stress, mitochondrial damage and cytotoxicity in Caco-2 cells. J Pharm Pharmacol 62: 943-950, 2010.

51. Martín S, González-Burgos E, Carretero ME and GómezSerranillos MP: Neuroprotective properties of Spanish red wine and its isolated polyphenols on astrocytes. Food Chemistry 128 40-48, 2011

52. Sharma R, Yang Y, Sharma A, Awasthi S and Awasthi YC: Antioxidant role of glutathione $\mathrm{S}$-transferases: protection against oxidant toxicity and regulation of stress-mediated apoptosis. Antioxid Redox Signal 6: 289-300, 2004
53. Yu MU, Yoo JM, Lee YS, et al: Altered de novo sphingolipid biosynthesis is involved in the serum deprivation-induced cell death in LLC-PK1 cells. J Toxicol Environ Health A 67: 2085-2094, 2004.

54. Katayama S and Mine Y: Antioxidative activity of amino acids on tissue oxidative stress in human intestinal epithelial cell model. J Agric Food Chem 55: 8458-8464, 2007.

55. Ina K, Kusugami K, Yamaguchi T, et al: Mucosal interleukin- 8 is involved in neutrophil migration and binding to extracellular matrix in inflammatory bowel disease. Am J Gastroenterol 92: 1342-1346, 1997.

56. Sanchez-Muñoz F, Dominguez-Lopez A and Yamamoto-Furusho JK: Role of cytokines in inflammatory bowel disease. World J Gastroenterol 14: 4280-4288, 2008.

57. Zhao Z, Shin HS, Satsu H, Totsuka M and Shimizu M: 5-caffeoylquinic acid and caffeic acid down-regulate the oxidative stress- and TNF-alpha-induced secretion of interleukin- 8 from Caco-2 cells. J Agric Food Chem 56: 3863-3868, 2008.

58. Satsu H, Hyun JS, Shin HS and Shimizu M: Suppressive effect of an isoflavone fraction on tumor necrosis factor-alpha-induced interleukin-8 production in human intestinal epithelial Caco-2 cells. J Nutr Sci Vitaminol (Tokyo) 55: 442-446, 2009.

59. Netsch M, Gutmann H, Aydogan C and Drewe J: Green tea extract induces interleukin-8 (IL-8) mRNA and protein expression but specifically inhibits IL-8 secretion in Caco-2 cells. Planta Med 72: 697-702, 2006. 